\title{
Trapped in the House: Internet Use and Loneliness in Students during the COVID-19 Pandemic
}

\section{Terperangkap dalam Rumah: Penggunaan Internet dan Kesepian pada Siswa selama Pandemi Covid-19}

\author{
Hendro Prabowo ${ }^{1}$, Mahargyantari Purwani Dewi ${ }^{2}$, Nur Aziz Afandi ${ }^{3}$, Henny Regina Salve ${ }^{4}$, Astri Nur \\ Kusumastuti ${ }^{5}$, Dinar Sari Eka Dewi ${ }^{6}$ \\ 1,2,4,5 Universitas Gunadarma, Depok, Indonesia \\ ${ }^{3}$ State Islamic Institute, Kediri, Indonesia \\ ${ }^{6}$ Universitas Muhammadiyah Purwokerto, Purwokerto, Indonesia
}

\section{ARTICLE INFO}

Article history:

DOI:

10.30595/pssh.v2i. 110

Submitted: Jul 16, 2021

Accepted: Aug 30, 2021

Published: Sept 24, 2021

\begin{abstract}
People in the world, including students, in social isolation during the Coronavirus pandemic, must stay at home, separate themselves from others and implement health protocols. As a consequence, university students must learn from home and distance learning online. This study aims to find the link between internet use and loneliness in 620 students in several cities in Java and Sumatra. The results showed the average internet usage was 10 hours per day, and the average nightly sleep was 6.5 hours per day, the average nap or nap was 1.3 hours per day. There is a very significant relationship between loneliness and online activity.
\end{abstract}

This work is licensed under a Creative Commons Attribution 4.0 International License.

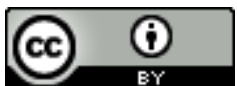

Keywords:

Internet use, loneliness, university students

\section{Corresponding Author:}

Henny Regina Salve

Universitas Gunadarma, Depok, Indonesia

Email: henny r@staff.gunadarma.ac.id

\section{INTRODUCTION}

Initially, Coronavirus was identified in Wuhan city and then spread throughout the world, including Indonesia. Until now, there are still many countries struggling to revolt against Covid-19 by trying to find a vaccine and trying to suppress the spread by implementing a lock-down system carried out by China, England, Italy, Spain, France, Ireland, Poland, Denmark, the Netherlands, El-Salvador, Belgium, Jordan, Lebanon, including Malaysia and the Philippines. Meanwhile, in Indonesia, Large-Scale Social Restrictions (PSBB) were imposed for 14 days in several cities and provinces. DKI Jakarta and East Java provinces had the highest number of COVID-19 cases (Bramasta, 2020; CNNIndonesia.com, 2020).

In October and November 2020, the European region again became the epicenter of COVID-19. Hence, several countries such as the UK, Ireland, Austria, France, Germany, Czech, Italy, the Netherlands imposed a lockdown again (Aida, 2020). The same thing happened in Indonesia, where the Government implemented an emergency Community Activity Restriction (PPKM) in Java and Bali from 11-25 January 2021, which was extended to February 8, 2021 (CNNIndonesia.com, 2021).

Over time, the COVID-19 virus has mutated into new variants, namely Delta and Kappa. The Delta variant has spread to 80 countries, and the Kappa variant has spread to 27 countries. The Delta variant became the dominant virus that triggered an increase in Covid cases in India, the UK, and Italy. In Indonesia, 90 percent of Covid-19 cases are caused by the Delta virus, which is very easily transmitted, especially to children (CNNIndonesia.com, 
According to UNESCO (2020), as of mid-April 2020, there are 1.3 billion understudies who are influenced by the school or college terminations in 195 countries, and more than 68 million understudies in Indonesia from preschool to college level learn from home online) due to school closures during the pandemic.

With the increase in COVID cases, the online teaching and learning system is still being carried out. In addition, social restrictions are also carried out to cut off physical or face-to-face social interaction. If the individual is isolated from family members and has to face several challenges, it can impact the mental health of incredibly lonely students. According to the World survey, during the COVID-19 pandemic in March 2021, about 33\% of adults were experiencing feelings of loneliness worldwide. Brazil's first position was occupied with $50 \%$ of respondents who said they felt lonely either often, always, or sometimes. Sometimes, she was followed by Turkey, India, and Saudi Arabia, with $43 \%$ to 46\%, where respondents least experienced loneliness (Varella, 2021). Research from Larague et al. (2021) finds that students most often experience loneliness as long as restrictions, of which $56.7 \%$ experienced moderate loneliness, and $23.6 \%$ tended to be lonely. It had been accounted for that students experienced more elevated levels of emotional loneliness when contrasted with social loneliness.

The Opinion and Lifestyle Survey (OPN) results from October 2020 to February 2021 showed that this number had increased to $7.2 \%$ of the adult population approximately 3.7 million adults). In addition, during the study period from October 2020 to February 2021, areas with a younger concentration of people aged 16-24 years) and areas with higher unemployment rates tended to have higher rates of loneliness (ons.gov.uk, 2021). In addition, based on the results of a CNNIndonesia.com (2020) poll on Twitter media to 753 readers, $61.6 \%$ admitted to feeling lonely during the COVID-19 pandemic, 453 readers answered the cause they experienced loneliness.

Loneliness can potentially trigger mental health, especially for young people. A survey from Making Common in October 2020 showed that 950 Americans, of whom 36\% of respondents reported feeling often or most of the time or all experienced loneliness, and most surprisingly, $61 \%$ of young people aged $18-25$ years and $51 \%$ of mothers with young children experience severe loneliness. $43 \%$ of young adults reported increased loneliness since the pandemic, and young adults suffered significant levels of loneliness and symptoms of anxiety and depression, as well as increased rates of heart disease and substance abuse. In addition, loneliness has a risk of heart disease, stroke, lowers the immune system, cognition, increases high blood pressure, increases premature death (Xia \& Li, 2018), increases body weight and obesity (Jung \& Luck-Sikorski, 2019), cause anxiety (Boursier et al., 2020), depression, alcohol use, child abuse, decrease sleep quality (Musthaq, 2014), trigger suicidal ideation, self-harm, and suicidal behavior (Chang et al., 2017; McClelland et al., 2020; Elbogen et al., 2021). Therefore, to reduce the loneliness experienced, someone will use the Internet. The world's population currently reaches 7.83 billion people during the pandemic. In January 2021, the total of internet surfers reached 4.66 billion people, an increase of $7.3 \%$ and an increase in the global Internet to $59.5 \%$ (Kemp, 2021). China has the most elevated internet surfer globally, trailed by India, America, and Indonesia. Meanwhile, in Indonesia, internet users reach 202 million people from the total population of Indonesia, which reaches 274.9 million people. In Indonesia, internet users increased to 27 million people $+16 \%$ between $2020-2021$ and grew to $73 \%$ in January 2021 (Kemp, 2021). Statistical data from VPNMentor (2021) shows that internet traffic in January 2021 for the Asia region was 4,803,660,196 and dominated by China, India, the USA, and Indonesia during the pandemic.

Data on the age of internet users in the United States in 2021, dominated by $99 \%$ of them are aged 18-29 years, then $98 \%$ are from 30-49 years old, which ranges from 98\%, and 94\% are from 50-64 years old, and 75\% are aged from 65 years and over. Recent reports note that 5.22 billion people access the Internet via mobile devices (Kamp, 2021). The most visited social media are Facebook, YouTube, WhatsApp, FB Messenger, WeChat, Instagram, Tiktok, Pinterest, Telegram, Twitter, and Line. Research by Mulyadi, Prabowo, Salve, and Ayuningsih (2020) shows that out of 991 respondents in Indonesia, they use internet activities via mobile to access social media, YouTube, browse the Internet, study online, entertainment applications, Covid news, online games, and so on.

Studies of Johnson in 2019 and 2020 (Johnson, 2021) noted a rise within the average daily use of social media worldwide, 145 minutes compared to the previous year, which was only 142 minutes of the day. In addition, a survey regarding the time spent daily with media during the pandemic (Kemp, 2021) shows that the time spent on the Internet via all devices is 6 hours 54 minutes, watching television, such as broadcasts, and streaming for 3 hours 24 minutes, social media for 2 hours 25 minutes, reading news and online newspapers for 2 hours 2 minutes, listening to streaming music for 1 hour 31 minutes, listening for 1 -hour radio, listening to podcasts for 54 minutes, playing video games for 1 hour 12 minutes. Based on the survey, the Philippines is the country that uses the most social media with a typical three hours and 53 minutes a day, compared to the US, which only uses social media for two hours and three minutes (Tanskovka, 2021).

Data from App Annie (cited in Kemp, 2021) also shows that Android users worldwide have spent 4 hours daily on their phones instead of watching television and have spent 3.5 trillion hours over the past 12 months. If you add up the total data, the average internet user spends 7 hours per day for all devices, the equivalent of more than 48 hours online per week, or two full days in the span of 1 week. If this number continues to increase throughout 2021, it will spend almost 12 trillion hours online or about 1.3 billion human years.

The Internet is like a double-edged sword, and the impact can be positive and negative. Supported research by Nowland, Necka, and Cacioppo (2017), experience loneliness shows a preference for using the Internet to help themselves interact socially and tends to be a way to replace time spent in face-to-face social activities. So, the 
Internet can be needed for lonely people as a kind of support to increase existing friendships and or make new ones. The results of a survey of online users worldwide in February 2019 (Tanskovka, 2021) showed most respondents stated that social media not only makes it easier to get information, communication, and freedom of expression but also worsens their privacy, causing political conditions to become increasingly polarized, and trigger daily distractions

\section{THEORITICAL FRAMEWORK}

The threat of Coronavirus and the consequences of social restriction policies (PSBB and PPKM) in Indonesia, forcing students to quarantine themselves for a long time and not gather and meet face-to-face for lectures and social activities. As a result, these students experience loneliness due to a lack of face-to-face social activities (Banerjee \& Rai, 2020; McQuaid, Cox, Ogunlana \& Jaworska, 2021; Laslo-Roth, George-Levi \& Margalit, 2021). In Indonesia, loneliness is a worldwide phenomenon (Varella, 2021; Dahlberg, 2021) and primarily occurs in students and young adults (Labrague et al., 2021). For example, see Horigian, Schmidt \& Feaster (2021) in the USA, Arslan (2021) in Turkey, or Zheng, Lin, He, Freudenreich, and Liu (2021) in China.

Loneliness is a subjective negative experience within the individual that is triggered when social relationships and interactions are not fulfilled (Labrague et al., 2021). Typically, there are three kinds of loneliness: existential loneliness, emotional loneliness, and social loneliness (White, 2019). Existential loneliness is an aspect of life that cannot be avoided and becomes an experience for individuals. Having a little loneliness can be beneficial for the soul to explore self-potential but becomes negative if it continues. Emotional loneliness is a condition in which someone has no feelings of connection or attachment to people. Social loneliness is a condition in which a person feels outside his group or relationship with his partner.

Students who experience loneliness can increase their use of the Internet to assist themselves in interacting socially and as a substitute for time spent in offline social activities (Nowland, Necka, and Cacioppo, 2018). In addition, Primack et al. (2017) found that the tendency to feel more isolated was higher among young adults with lower high school seniors (social media use) than young adults with lower high school seniors. Research by Alheinedi, Al Sumait, Al Sumait, and Smith (2021) also shows that problematic internet use is related to loneliness, where loneliness scores are highly correlated with the number of hours spent online; the higher the hours of internet use, the upper the loneliness.

Mohan and Ravindran's (2020) research also finds that high loneliness can lead a person to excessively using the Internet, triggering problematic internet use (PIU) and hindering daily life. This excessive internet use occurs, for example, in Bangladesh (Islam et al., 2020) and worldwide (Awan et al., 2021).

Based on this explanation, it can be concluded that COVID-19 has put everyone in danger, even though many efforts have been made to suppress the Coronavirus and reduce COVID-19 cases. This condition has the potential to increase and even worsen psychological problems. Therefore, this study aims to determine the relationship between internet use and loneliness during the COVID-19 pandemic.

\section{RESEARCH METHODOLOGY}

The research subjects were 622 students in several cities in Java and Sumatra aged 17-25 years and came from psychology, ushuludin, economics, communication, and law study programs from private and state universities. The method used in research is quantitative by using an online questionnaire containing the loneliness scale and internet activity scale. The online questionnaire is collected through a google form, where data in MS Excell form is transferred into SPSS Software to be analyzed descriptively and inferentially.

The questionnaire through the google form was conducted to the students taught by the researchers who are also lecturers. So, the respondents are also students who study online taught by the researchers.

The Loneliness Scale was adapted from the UCLA Loneliness Scale (Version 3) developed by Russell (1996). The Loneliness Scale consists of a 20-item Likert Scale with four options: Often Feel This Way, Sometimes Feel This Way, Rarely Feel This Way and Never Feel This Way. The 20-item Internet Activity Scale was adapted from The Compulsive Internet Use Scale (CIUS) developed by Meerkerk, Van Den Eijnden, Vermulst and Garretsen (2009). The scale consists of 15 items with five options: Strongly Agree, Agree, Neutral, Disagree, and Strongly Disagree. The Loneliness Scale Likert scale has a reliability coefficient Alpha $=0.731$. and Likert Scale Internet Activity Scale has a reliability coefficient of Alpha $=0.882$.

\section{RESULTS AND DISCUSSION}

Mostly, participants are from Depok as $43.8 \%$ and followed by Kediri 34.7\%. More than a half is 17-20 years old $(60.3 \%)$. Details of the participants can be seen as below:

Table 1. Hometown of Respondent

\begin{tabular}{lcclcc}
\hline \multicolumn{1}{c}{ City } & Amount & \% age & \multicolumn{1}{c}{ City } & Amount & \% age \\
\hline Depok & 273 & $43.8 \%$ & Banda Aceh & 8 & $1.2 \%$ \\
\hline Kediri & 216 & $34.7 \%$ & Bogor & 8 & $1.2 \%$ \\
\hline Jakarta & 39 & $6.2 \%$ & Yogyakarta & 4 & $0.6 \%$
\end{tabular}




\begin{tabular}{lcclcc} 
Tangerang & 12 & $1.9 \%$ & Bandung & 4 & $0.6 \%$ \\
\hline Surabaya & 10 & $1.6 \%$ & Others & 40 & $6.4 \%$ \\
\hline Tulungagung & 8 & $1.2 \%$ & & & \\
\hline
\end{tabular}

Table 2. Demographic of Respondent

\begin{tabular}{cclc}
\hline Age & \multicolumn{3}{c}{ Departement } \\
\hline $17-20$ & $375(60.3 \%)$ & Psychology & $276(44.5 \%)$ \\
\hline $21-25$ & $247(39.7 \%)$ & Ushuludin & $176(28.3 \%)$ \\
\hline Gender & & Economics & $32(5.1 \%)$ \\
\hline Male & $133(21.2 \%)$ & Communication & $17(2.7 \%)$ \\
\hline Female & $489(78.8 \%)$ & Law & $12(1.9 \%)$ \\
\hline & & Others & $100(17.2 \%)$ \\
\hline
\end{tabular}

During the pandemic, the social media used by respondents include WhatsApp, Instagram, Twitter, Tiktok, Youtube, Telegram, Facebook, and Line (table 3). These results are consistent with several studies in Indonesia, Italy, Pakistan, and Brazil, which found that WhatsApp, Instagram, Twitter, Line, Facebook, Youtube, and Tiktok became popular social media during the pandemic (Dean 2021; Mulyadi et al., 2020; Boursier 2020; Hussain, 2020; and González-Padilla, \& Tortolero-Blanco, 2020).

As for learning, the respondents use Google Meets, Zoom, Google Classroom, and Skype. Similar to the study by González-Padilla, and Tortolero-Blanco (2020) in Brazil where YouTube, Skype, or Zoom are social media use for online learning.

Table 3. The Use of Media Social and Learning Application

\begin{tabular}{lclc}
\hline Social Media & Amount of Respondent & Learning apps & Amount of Respondent \\
\hline WhatsApp & 544 & Google Meets & 478 \\
\hline Instagram & 507 & Zoom & 460 \\
\hline Twitter & 405 & Google Classroom & 53 \\
\hline Line & 141 & Skype & 11 \\
\hline Facebook & 116 & & \\
\hline Youtube & 59 & & \\
\hline Telegram & 50 & & \\
\hline Tiktok & 38 & & \\
\hline
\end{tabular}

Table 4. Social Media Use during Pandemic

\begin{tabular}{|c|c|c|}
\hline Authors & Respondent & Result \\
\hline Dean (2021) & $\begin{array}{l}3.96 \text { billion social media } \\
\text { users worldwide }\end{array}$ & $\begin{array}{l}\text { The most used were Facebook ( } 2.70 \text { billion users), } \\
\text { TikTok ( } 1 \text { billion users), and Instagram, Messenger, } \\
\text { WeChat (Total number about } 1 \text { billion users or more) }\end{array}$ \\
\hline Boursier et al. (2020) & $\begin{array}{l}715 \text { adults, } 18-72 \text { years } \\
\text { old, Italy }\end{array}$ & $\begin{array}{l}\text { The most used were WhatsApp }(90.2 \%) \text {, Instagram } \\
(64.2 \%) \text {, Facebook }(63.6 \%) \text {, Facebook Messenger } \\
(16.1 \%) \text {, and Twitter }(5.3 \%) \text {. }\end{array}$ \\
\hline Hussain (2020) & Pakistan & $\begin{array}{l}\text { The media that are the most sources for disseminating } \\
\text { information and news are Facebook, Twitter, } \\
\text { YouTube, Instagram, Snapchat, and WhatsApp. }\end{array}$ \\
\hline $\begin{array}{l}\text { González-Padilla, } \\
\text { and Tortolero- } \\
\text { Blanco (2020) }\end{array}$ & Brazil & $\begin{array}{l}\text { Social media that support medical education through } \\
\text { online live and recorded webinars through YouTube, } \\
\text { Skype, or Zoom }\end{array}$ \\
\hline $\begin{array}{l}\text { Mulyadi, Prabowo, } \\
\text { Salve and } \\
\text { Ayuningsih (2020) }\end{array}$ & $\begin{array}{l}991 \text { respondents, } \\
\text { students from } 21 \\
\text { provinces in Indonesia }\end{array}$ & $\begin{array}{l}\text { Popular media are WhatsApp, Instagram, Twitter, } \\
\text { Facebook, Line, Youtube, and Tiktok }\end{array}$ \\
\hline
\end{tabular}

The use of social media and the Internet to connect social and learn online ultimately resulted in a tendency of internet use problems in students related to internet dependency in China (Sun, 2020), gaming behavior in India (Balhara et al., 2020), and internet addiction in Indonesia (Siste et al., 2020).

Table 5. Internet Use Problem during Pandemic

\begin{tabular}{lll}
\hline Authors & Respondent & Result \\
\hline Sun et al (2021) & 6,416 Chinese, general population & During the pandemic, respondents reported a \\
& $46.8 \%$ increase in internet dependency and a \\
& $16.6 \%$ increase in internet usage hours. \\
\hline
\end{tabular}


Balhara et al. (2020) 393 Indian college students

Siste et al. (2020)
4,734 Indonesian adults, $31.84 \pm$

7.73 years old from 34 provinces
The increase in gaming behavior was associated with examination-related stress and the belief that gaming can cope with stress

During the pandemic, the prevalence of internet addiction was $14.4 \%$, and the online duration increased to $52 \%$.

Internet use of the respondents was found to average 10.08 hours per day, while the average number of hours of night sleep was 6.5 hours per day plus an average siesta (nap) of 1.34 hours per day (table 6). Internet use of 10.08 hours per day is an increase over previous studies, which only 6.96 hours per day (Mulyadi et al.,2020) or 6,17 hours per day (Prabowo et al., 2020). During pandemics, the nap is a new phenomenon and only takes 15-20 minutes during break time (Lammers-van der Holst, Murphy, Wise \& Duffy, 2020). The results of this study are like those of the study by Prabowo et al. (2020) that find there are 52 (4.23\%) respondents who had a nap duration of 4 hours or more and $507(41.29 \%)$ respondents with a nap duration of 2-3 hours. This result of night sleep is better than the study by Mulyadi et al. (2020) with an average of 6.07 hours per day and a survey by Prabowo et al. (2020) with an average of 6.17 hours per day.

Table 6. Descriptive Statistic of Respondent

\begin{tabular}{lccccc}
\hline & N & Minimum & Maximum & Mean & $\begin{array}{c}\text { Std. } \\
\text { Deviation }\end{array}$ \\
\hline Internet Use Duration (hour) & 622 & 1 & 20 & 10.08 & 4.42 \\
\hline Sleep Duration (hour) & 622 & 2 & 19 & 6.49 & 1.50 \\
\hline Siesta Duration (hour) & 622 & 0 & 7 & 1.34 & 1.05 \\
\hline Online Activity Scale & 622 & 18 & 75 & 39.32 & 8.32 \\
\hline Loneliness Scale & 622 & 21 & 66 & 40.18 & 8.49 \\
\hline
\end{tabular}

The statistical analysis results using Pearson correlation showed the value of $r=0.297(\mathrm{p}<0.01)$, so it can be concluded that there is a very significant correlation between internet activity and loneliness. Several authors have concluded that quarantine and social isolation can lead to loneliness (Banerjee \& Rai, 2020; Hartt, 2020; Hwang, Rabheru, Reichman \& Ikeda, 2020; Wu, 2020; McQuaid, Cox, Ogunlana \& Jaworska, 2021; Laslo-Roth, GeorgeLevi \& Margalit, 2021). The use of social media to overcome loneliness has been widely used. The study also found a link between internet activity and loneliness in students. These findings support several previous studies, such as Cauberghe et al. (2021) in Belgium, Musetti et al. (2020) and Boursier et al. (2020) in Italy, Alhneidi et al. (2021) in Kuwait and Saudi Arabia, Lisitsa et al. (2020) in the USA, and Koh and Liew (2020) on Twitter users.

Table 7. Relation between Internet Use/Activity and Loneliness during Pandemic

\begin{tabular}{lll}
\hline Authors & Respondent & Result \\
\hline Cauberghe et al. (2021) & $\begin{array}{l}2,165 \text { between 13 - 19 years old, } \\
\text { Belgium }\end{array}$ & $\begin{array}{l}\text { Respondents who experienced loneliness } \\
\text { were more likely to use social media to cope } \\
\text { with their lack of social contact }\end{array}$ \\
\hline Musetti et al. (2020) & $\begin{array}{l}\text { 356 adolescents' students, Parma, } \\
\text { Italy }\end{array}$ & $\begin{array}{l}\text { There is a relationship between loneliness } \\
\text { and the problem of internet use }\end{array}$ \\
\hline Boursier et al. (2020) & 715 adults, 18 - 72 years old, Italy & $\begin{array}{l}\text { Isolation can reinforce the sense of loneliness } \\
\text { and strengthening the need to be part of } \\
\text { virtual communities }\end{array}$ \\
\hline Alheneidi et al. (2021) & $\begin{array}{l}\text { 593 participants, Arabs aged 18 } \\
\text { years and over, Kuwait and Saudi } \\
\text { Arabia }\end{array}$ & $\begin{array}{l}\text { There is an association between loneliness } \\
\text { and problematic internet use }\end{array}$ \\
\hline Lisitsa et al. (2020) & $\begin{array}{l}\text { 1,674 American adults, 18-24 } \\
\text { years old, King County, } \\
\text { Washington }\end{array}$ & $\begin{array}{l}\text { During the pandemic, young adults } \\
\text { experienced more loneliness than older } \\
\text { adults, exhibited higher increases in social } \\
\text { media use, and lower seeking of social } \\
\text { support. }\end{array}$ \\
\hline Koh and Liew (2020) & Individual Twitter users & $\begin{array}{l}\text { 4,492 Twitter feeds were included and } \\
\text { classified into three themes: Community } \\
\text { impact of loneliness; Social distancing and its } \\
\text { effects on loneliness, and mental health } \\
\text { effects of loneliness. }\end{array}$ \\
\hline
\end{tabular}




\section{CONCLUSION}

This study descriptively found that during the COVID-19 pandemic, students became trapped in the house with some traits of sleep deprivation, excess internet use, use of social media for socialization and learning. The study inferentially also found there is a significant link between internet activity and loneliness. The results of this study have similarities with some previous research in Indonesia and the world.

\section{REFERENCES}

Alheneidi, H., Al Sumait, L., Al Sumait, D., \& Smith, A. P. (2021). Loneliness and problematic internet use during covid-19 lock-down. Behavioral Sciences, 11(1), 1-11. doi:10.3390/bs11010005.

Arslan, G. (2021). Loneliness, college belongingness, subjective vitality, and psychological adjustment during coronavirus pandemic: Development of the college belongingness questionnaire. Journal of Positive School Psychology, 5(1), 17-31. DOI: 10.47602/jpsp.v5i1.240

Awan, H. A., Aamir, A., Diwan, M. N., Ullah, I., Pereira-Sanchez, V., Ramalho, R., ... \& Virani, S. (2021). Internet and pornography use during the covid-19 pandemic: Presumed impact and what can be done. Frontiers in Psychiatry, 12, 220. DOI: 10.3389/fpsyt.2021.623508.

Balhara, Y. P. S., Kattula, D., Singh, S., Chukkali, S., \& Bhargava, R. (2020). Impact of lock-down following COVID19 on the gaming behavior of college students. Indian Journal Of Public Health,64(6), 172-176. DOI: 10.4103/ijph.IJPH_465 20.

Banerjee, D., \& Rai, M. (2020). Social isolation in covid-19: The impact of loneliness. International Journal of Social Psychiatry, 66(6), 525-527. DOI: 10.1177/0020764020922269.

Boursier, V., Gioia, F., Musetti, A., \& Schimmenti, A. (2020). Facing loneliness and anxiety during the covid-19 isolation: the role of excessive social media use in a sample of Italian adults. Frontiers in Psychiatry, 11(586222). 1-10. DOI: $10.3389 /$ fpsyt.2020.586222.

Casagrande, M., Forte, G., Tambelli, R., \& Favieri, F. (2021). The coronavirus pandemic: a possible model of the direct and indirect impact of the pandemic on sleep quality in Italians. Nature and Science of Sleep, 13, 191-199. DOI: 10.2147/NSS.S285854.

Cauberghe, V., Van Wesenbeeck, I., De Jans, S., Hudders, L., \& Ponnet, K. (2021). How adolescents use social media to cope with feelings of loneliness and anxiety during covid-19 lock-down. Cyberpsychology, Behavior, and Social Networking, 24(4), 250-257. DOI: 10.1089/cyber.2020.0478.

Chang, E. C, Wan, L., Li, P., Guo, Y., He, J., Gu, Y., Li, X., Zhang, Z., et al. (2017). Loneliness and suicidal risk in young adults: does believing in a changeable future help minimize suicidal risk among the lonely?. Journal of Psychology: Interdisciplinary and Applied, 151(5), 453-463. DOI: 10.1080/00223980.2017.1314928

CNN Indonesia. (2020, September 11). Perjalanan PSBB jakarta hingga kembali ke titik nol. Newsweek. https://www.cnnindonesia.com/nasional/20200911061829-20-545178/perjalanan-psbb-jakarta-hingga-kembalike-titik-nol

CNN Indonesia. (2021, January 21). Pemerintah resmi perpanjang PPKM jawa-bali hingga 8 februari. Newsweek.. https://www.cnnindonesia.com/nasional/20210121131343-20-596649/pemerintah-resmi-perpanjang-ppkm-jawabali-hingga-8-februari

CNN Indonesia. (2021, July 1). Aturan lengkap ppkm darurat di jawa bali selama 3-20 juli. Newsweek. https://www.cnnindonesia.com/nasional/20210701124917-20-661769/aturan-lengkap-ppkm-darurat-di-jawa-baliselama-3-20-juli

CNN Indonesia. (2021, July 6). Beda varian baru virus corona delta dan kappa. Newsweek.. https://www.cnnindonesia.com/teknologi/20210706084344-199-663659/beda-varian-baru-virus-corona-deltadan-kappa/2

CNN Indonesia. (2021, March 12) 5 mutasi covid-19 dunia hingga RI, lebih menular dan pintar. Newsweek.. https://www.cnnindonesia.com/teknologi/20210312141414-199-616717/5-mutasi-covid-19-dunia-hingga-rilebih-menular-dan-pintar

Covid19. (2021, July 7). Data sebaran. https://covid19.go.id/peta-sebaran

Dahlberg, L. (2021). Loneliness during the COVID-19 pandemic, Aging \& Mental Health, 25(7), 1161-1164. DOI: $10.1080 / 13607863.2021 .1875195$.

Dean, B. (2021). Social network usage \& growth statistics: How many people use social media in 2021? https://backlinko.com/social-media-users

Elbogen., E. B., Lanier, M., Blakey, S. M., Wagner, H. R., Tsai, J. (2021). Suicidal ideation and thoughts of self-harm during the covid-19 pandemic: the role of covid-19-related stress, social isolation, and financial strain. Depression and Anxiety. DOI: $10.1002 /$ da. 23162

Ferdiaz, N. Y. (2021, Juni 30). Aturan baru protokol kesehatan 10m wajib diterapkan untuk kurangi kasus covid-19. https://health.grid.id/read/352765551/aturan-baru-protokol-kesehatan-10m-wajib-diterapkan-untuk-kurangikasus-covid-19?page=all

González-Padilla, D. A., \& Tortolero-Blanco, L. (2020). Social media influence in the COVID-19 pandemic. International Braz J Urol, 46, 120-124. doi: 0.1590/S1677-5538.IBJU.2020.S121.

Hartt, M. (2020). COVID-19: a lonely pandemic. Cities \& Health, 1-3. DOI: 10.1080/23748834.2020.1788770.

Horigian, V. E., Schmidt, R. D., \& Feaster, D. J. (2021). Loneliness, mental health, and substance use among us young

Proceedings homepage: https://conferenceproceedings.ump.ac.id/index.php/pssh/issue/view/7 
adults during covid-19. Journal of Psychoactive Drugs, 53(1), 1-9. DOI: 10.1080/02791072.2020.1836435.

Hussain, W. (2020). Role of social media in the covid-19 pandemic. The International Journal of Frontier Sciences, 4(2), 59-60. DOI: 10.37978/tijfs.v4i2.144.

Hwang, T. J., Rabheru, K., Peisah, C., Reichman, W., \& Ikeda, M. (2020). Loneliness and social isolation during the COVID-19 pandemic. International Psychogeriatrics, 32(10), 1217-1220. DOI: 10.1017/S1041610220000988

Islam, M. S., Sujan, M. S. H., Tasnim, R., Ferdous, M. Z., Masud, J. H. B., Kundu, S., ... \& Griffiths, M. D. (2020). Problematic internet use among young and adult population in Bangladesh: Correlates with lifestyle and online activities during the COVID-19 pandemic. Addictive behaviors reports, 12, 100311. DOI: $\underline{10.1016 / \text { j.abrep.2020.100311 }}$

Jahrami, H., BaHammam, A. S., Bragazzi, N. L., Saif, Z., Faris, M., \& Vitiello, M. V. (2021). Sleep problems during the COVID-19 pandemic by population: a systematic review and meta-analysis. Journal of Clinical Sleep Medicine, 17(2), 299-313. DOI: 10.5664/jcsm.8930.

Johnson, J. (2021). Age distribution of internet users worldwide 2019. https://www.statista.com/statistics/272365/agedistribution-of-internet-users-worldwide/

Jung, F.U., \& Luck-Sikorski, C. (2019). Overweight and lonely? A representative study on loneliness in obese people and its determinants. Obesity Facts, 12(4), 440-447. DOI: 10.1159/000500095.

Kemp, S. (2021). Digital 2021: The latest insights into the 'state of digital.' https://wearesocial.com/blog/2021/01/digital-2021-the-latest-insights-into-the-state-of-digital.

Koh, J. X., \& Liew, T. M. (2020). How loneliness is talked about in social media during COVID-19 pandemic: Text mining of 4,492 Twitter feeds. Journal of Psychiatric Research. DOI: 10.1016/j.jpsychires.2020.11.015.

Lammers-van der Holst, H. M., Murphy, A. S., Wise, J., \& Duffy, J. F. (2020). Sleep tips for shift workers in the time of the pandemic. Southwest Journal of Pulmonary \& Critical Care, 20(4), 128-130.

Labrague, L. J., De los Santos, J. A. A., \& Falguera, C. C. (2021). Social and emotional loneliness among college students during the covid-19 pandemic: The predictive role of coping behaviors, social support behaviors, social support, and personal resilience. Perspectives in Psychiatric Care, December. DOI: 10.1111/ppc.12721.

Laslo-Roth, R., George-Levi, S., \& Margalit, M. (2021). Hope during the COVID-19 outbreak: coping with the psychological impact of quarantine. Counselling Psychology Quarterly, 1-15. DOI: 10.1080/09515070.2021.1881762.

Lisitsa, E., Benjamin, K. S., Chun, S. K., Skalisky, J., Hammond, L. E., \& Mezulis, A. H. (2020). Loneliness among young adults during a covid-19 pandemic: The mediational roles of social media use and social support seeking. Journal of Social and Clinical Psychology, 39(8), 708-726.

McClelland, H., Evans, J, J., Nowland, R., Ferguson, E., O'Connor, R, C. (2020). Loneliness as a predictor of suicidal ideation and behavior: A systematic review and meta-analysis of prospective studies. Journal of Affective Disorders, 274(1), 880-896. Doi: 10.1016/j.jad.2020.05.004.

McQuaid, R. J., Cox, S. M., Ogunlana, A., \& Jaworska, N. (2021). The burden of loneliness: Implications of the social determinants of health during COVID-19. Psychiatry Research, 296, 113648. DOI: 10.1016/j.psychres. 2020.113648 .

Mulyadi, S., Prabowo, H., Salve, H. R., \& Ayuningsih, A. M. (2020). Sleep duration, internet use duration, and anxiety on university student during Covid-19 Pandemic. Proceedings of the 5th NA International Conference on Industrial Engineering and Operations Management Detroit, Michigan, USA, August 10 - 14, 2020.

Musetti, A., Corsano, P., Boursier, V., \& Schimmenti, A. (2020). Problematic internet use in lonely adolescents: the mediating role of detachment from parents. Clinical Neuropsychiatry, 17(1), 3-10. DOI: 10.36131/clinicalnpsych20200101.

Mustaq, R., Shoib, S., Shah, T., \& Mustaq, S. (2014). Relationship between loneliness, psychiatric disorders, and physical health? A review on the psychological aspects of loneliness. Journal of Clinical and Diagnostic Research, 8(9), WE01-WE04. DOI: 10.7860/JCDR/2014/10077.4828.

Nowland, R., Necka, E. A., \& Cacioppo, J. T. (2018). Loneliness and social internet use: pathway reconnection in a digital world?. Journal Perspectives on Psychological Science, 13(1), 70-87. DOI: 10.1177/1745691617713052.

Nowland, R., Necka, E. A., \& Cacioppo, J. T. (2018). Loneliness and social Internet use: Pathways to reconnection in a digital world? Perspectives on Psychological Science: A Journal of the Association for Psychological Science, 13(1), 70-87. doi.org/10.1177/1745691617713052

Prabowo, H., Salve, H.R., Dewi, M.P., Afandi, N.A. Lailani, F., Wijaya, A., \& Dewi, D. S. E. (2020). Kecenderungan perilaku baru pada remaja di Indonesia selama pandemi COVID-19. Prosiding E- Conference Konsorsium Psikologi Ilmiah Nusantara 2020, 731-741.

Primack, B. A., Shensa, A., Sidani, J. E., Whaite, E. O., yi Lin, L., Rosen, D., ... \& Miller, E. (2017). Social media use and perceived social isolation among young adults in the US. American Journal of Preventive Medicine, 53(1), 18. 10.1016/j.amepre.2017.01.010.

Robillard, R., Dion, K., Pennestri, M. H., Solomonova, E., Lee, E., Saad, M., ... \& Kendzerska, T. (2021). Profiles of sleep changes during the COVID-19 pandemic: Demographic, behavioral and psychological factors. Journal of Sleep Research, 30(1), 1-12. DOI: 10.1111/jsr.13231.

Saiful Mujani Research and Consulting (SMRC). (2021). Asesmen publik tentang pendidikan online di masa covid-19. https://saifulmujani.com/wp-content/uploads/2020/08/SMRCSurvei-Telepon_5-8-Ags-2020_-BELAJAR- 
ONLINE-2.pdf

Siste, K., Hanafi, E., Lee Thung Sen, H. C., Adrian, L. P. S., Limawan, A. P., Murtani, B. J., \& Suwartono, C. (2020). The impact of physical distancing and associated factors towards internet addiction among adults in Indonesia during a covid-19 pandemic: A Nationwide web-based study. Frontiers in Psychiatry, 11 . 10.3389/fpsyt.2020.580977

Sun, Y., Li, Y., Bao, Y., Meng, S., Sun, Y., Schumann, G., ... \& Shi, J. (2020). Brief report: increased addictive internet and substance use behavior during the COVID-19 pandemic in China. The American Journal on Addictions, 29(4), 268-270. DOI: 10.1111/ajad.13066.

Tankovska, H. (2021, February 8). Daily media social life 2019. https://www.statista.com/statistics/433871/dailysocial-media-usage-worldwide/

Tankovska, H. (2021, January 28). Global impact of social media on daily life 2019. https://www.statista.com/statistics/1015131/impact-of-social-media-on-daily-life-worldwide/

UNESCO. (2021, May 21). 1.3 billion learners are still affected by the school or university closures, as educational institutions start reopening around the world, says UNESCO. https://en.unesco.org/news/13-billion-learners-arestill-affected-school-university-closures-educational-institutions

Vpnmentor. (2021, March 16). Tren internet 2021. statistik \& fakta di amerika serikat dan seluruh dunia. https://id.vpnmentor.com/blog/trend-internet-vital/

$\begin{array}{llll}\text { Worldometers. } & \text { (2021, July } & \text { Coronavirus. }\end{array}$ https://www.worldometers.info/coronavirus/?utm_campaign=homeAdUOA?Si

Wu, B. (2020). Social isolation and loneliness among older adults in the context of covid-19: A global challenge. Global Health Research and Policy, 5(1), 1-3.

Xia, N., \& Li, H. (2018). Loneliness, social isolation, and cardiovascular health. Antioxidants and Redox Signaling, 28(9), 837-851. DOI: $10.1089 /$ ars.2017.7312.

Zheng, Q., Lin, X., He, L., Freudenreich, T., \& Liu, T. (2021). Impact of the perceived mental stress during the covid19 pandemic on medical students' loneliness feelings and future career choice: A Preliminary survey study. Frontiers in Psychiatry, 12, 860-871. DOI: 10.3389/fpsyt.2021.666588 